\title{
Physiological and Genetic Bases of the Circadian Clock in Plants and Their Relationship with Herbicides Efficacy ${ }^{1}$
}

\author{
Bases Fisiológicas e Genéticas do Relógio Circadiano em Plantas e sua Relação com a Eficácia \\ de Herbicidas
}

\author{
DALAZEN, G. ${ }^{2}$, and MEROTTO JR., A. ${ }^{2}$
}

\begin{abstract}
In order to adapt to daily environmental changes, especially in relation to light availability, many organisms, such as plants, developed a vital mechanism that controls time-dependent biological events: the circadian clock. The circadian clock is responsible for predicting the changes that occur in the period of approximately 24 hours, preparing the plants for the following phases of the cycle. Some of these adaptations can influence the response of weeds to the herbicide application. Thus, the objectives of this review are to describe the physiological and genetic mechanisms of the circadian clock in plants, as well as to demonstrate the relationship of this phenomenon with the effectiveness of herbicides for weed control. Relationships are described between the circadian clock and the time of application of herbicides, leaf angle and herbicide interception, as well as photosynthetic activity in response to the circadian clock and herbicide efficiency. Further, it is discussed the role of phytochrome B (phyB) in the sensitivity of plants to glyphosate herbicide. The greater understanding of the circadian clock in plants is essential to achieve greater efficiency of herbicides and hence greater control of weeds and higher crop yields.
\end{abstract}

Keywords: time of herbicide application, weeds, photoreceptors, phytochromes.

RESUMO - Para se adaptarem às variações ambientais diárias, principalmente em relação à disponibilidade de luz, muitos organismos, como as plantas, desenvolveram um mecanismo vital que controla eventos biológicos dependentes do tempo: o relógio circadiano. Esse relógio é responsável por prever as variações que ocorrem no periodo de aproximadamente 24 horas, preparando as plantas para as próximas fases do ciclo. Algumas dessas adaptações podem influenciar na resposta das plantas daninhas à aplicação de herbicidas. Dessa forma, os objetivos desta revisão foram descrever os mecanismos fisiológicos e genéticos do relógio circadiano em plantas, assim como demonstrar a relação desse fenômeno com a eficácia de herbicidas em plantas daninhas. Foram descritas as relações entre o relógio circadiano e o horário de aplicação de herbicidas, o ângulo foliar e área de interceptação de herbicidas pelas folhas, assim como a atividade fotossintética em resposta ao relógio circadiano e a eficiência de herbicidas. Ainda, foi discutido o papel do fitocromo $B$ (phyB) na sensibilidade de plantas ao herbicida glifosato. O maior entendimento do relógio circadiano de plantas é fundamental para se obter maior eficiência dos herbicidas e, consequentemente, maior controle das plantas daninhas e maior rendimento das culturas.

Palavras-chave: horário de aplicação de herbicidas, plantas daninhas, fotorreceptores, fitocromos.

\section{INTRODUCTION}

Due to their sessile lifestyle, plants develop mechanisms that allow them to adjust to environmental variations. Such adaptations are related to large time-scale time variations, such as the environmental oscillations over the years, allowing the species to perpetuate during several generations. Adaptations may also occur in medium time-scale, considering the adaptations that occur in one plant growth cycle overcoming the environmental

Recebido para publicação em 19.8.2015 e aprovado em 26.10.2015.

2 Universidade Federal do Rio Grande do Sul(UFRGS), Porto Alegre-RS, Brazil, < giliardidalazen@gmail.com>. 
variations over a season or year, and in small time-scale, when plants adapt to the daily environmental oscillations, mainly in relation to light availability (Más \& Yanovsky, 2010). Many organisms, such as plants, developed a vital mechanism that controls time-dependent biological events: the circadian clock (Imaizumi, 2010).

The circadian clock (from Latin circa diem, which means "approximately one day") acts to regulate several events on plants. Approximately $25 \%$ of the Arabidopsis genes that encode proteins with several functions are regulated by the circadian clock (Hazen et al., 2009). Amongst its functions are the regulation of germination, enzymatic activity, stomatal movements and gas exchanges, photosynthesis, flower blossoming and the emission of fragrances (McClang et al., 2006). Some of these functions, both morphological and physiological, are related to the action of herbicides and may be vital to the success or failure of weed control.

Therefore, the objectives of this review are to describe the physio-genetic bases of the circadian clock in plants and relate them to the management of weeds and the efficiency of herbicides.

\section{SIGNALING AND SINCHRONIZATION OF THE CIRCADIAN CLOCK}

The circadian clock consists of a central oscillator with endogenous regulation, which allows this rhythm to persist for several days or weeks, even under continuous environmental conditions (continuous light or darkness) (Wijnen \& Young, 2006). In addition to the central oscillator, other routes are responsible for its adjustment in response to the daily and seasonal variations of light and temperature cycles. These external stimuli are known as Zeitgeber signals (Wijnen \& Young, 2006). The endogenous regulation mechanism coordinates oscillations in biological processes with duration of approximately 24 hours (Más \& Yanovsky, 2010).

The circadian clock is a cyclic phenomenon, basically defined by three parameters (Figure 1): period, phase, and amplitude. The period is the necessary time for a cycle to be completed, measured as the time between two consecutive maximum (peaks) or minimal (valleys) periods. Usually, the period lasts approximately 24 hours. The phase is defined as any point in the cycle that is known for its relation to the rest of the cycle. The most obvious phase points are the peak and valley positions. Finally, the amplitude is considered as the distance between the peak and the valley. The amplitude of a biological rhythm may often vary, while the period remains unchanged (McClung et al., 2006).

The perception of the luminous sign in plants is made by photoreceptors, which include phytochromes (phy), cryptochromes, phototropins, ZTL/ADO family proteins, in addition to a protein family of photoreceptors responsible for absorbing the ultraviolet light (UV-B) (Franklin et al., 2005). Phytochromes are the main photoreceptors, and they are responsible for absorbing the red (R) and farred (FR) radiation. There are two forms of these photoreceptors, which are photoreversible: $\operatorname{Pr}$ and Pfr. By absorbing red light, the Pr form converts to Pfr, which, by absorbing far-red light converts to Pr (Rockwell et al., 2006). The active form of phytochrome is Pfr, since the responses of the phytochrome are induced by the red light (Jiao et al., 2007). In rice (Oryza sativa), there are three phytochromes (phyaA-phyC), and in Arabdopsis, there are five (phyA-phyE). Phytochrome B (phyB) is the main photoreceptor involved in the control of plant growth and development, acting to synchronize the circadian clock (Nagy \& Schäfer, 2002). The interaction between phyA and phyB on the Pfr forms, together with specific cellular factors, are necessary for the translocation of the signal to the nuclei to occur, and for the

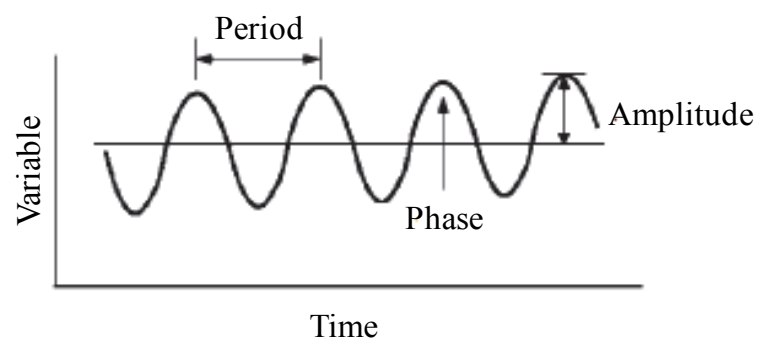

Adapted from McClung et al. (2006).

Figure 1 - Constituting parameters of the circadian clock. 
metabolic cascade to start in response to the luminous signal (Bae \& Choi, 2008; Pfeiffer et al., 2012).

\section{REGULATION OF THE CIRCADIAN CLOCK IN PLANTS}

Up to now, over 20 components related to the circadian clock in Arabidopsis were identified, and homologous genes in other plants have been observed, indicating that this system is highly preserved in plants (Song et al., 2010; Hsu \& Harmer, 2014). The proteins that belong to the circadian clock act at different times during the night and the day, reciprocally regulating the expression of other genes, on the transcriptional and post-transcriptional level (Hsu \& Harmer, 2014). The components that regulate the circadian clock (Figure 2) may be divided into four groups: morning, daytime, afternoon, and evening regulation components.

The morning regulation components include the transcription factors CCA 1 (CIRCADIAN CLOCK-ASSOCIATED 1) and LHY (LATE ELONGATED HYPOCOTYL). The amounts of transcripts and proteins are highly abundant during the morning (Lu et al., 2009). These proteins act to inhibit the expression of the TOC1 (TIMING OF CAB EXPRESSION)

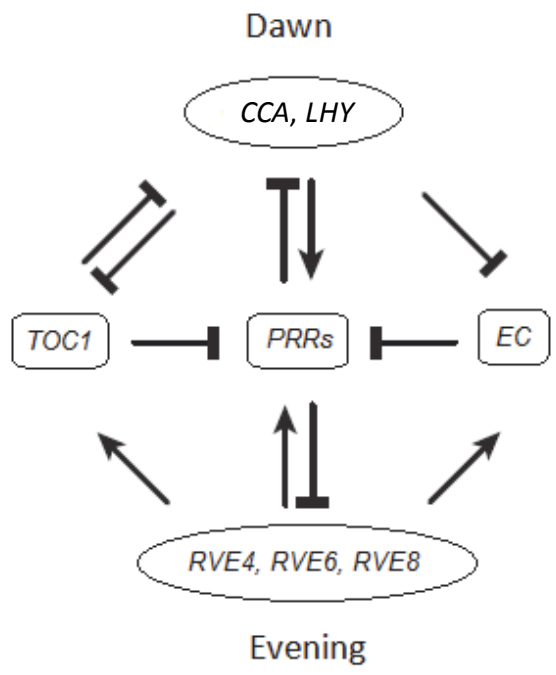

Adapted from Hsu \& Harmer (2014).

Figure 2 - Simplified model of the transcriptional regulation among the classes of the circadian clock. gene, the main component of the evening phase of the circadian clock, also known as PRR1 (PSEUDO-RESPONSE REGULATOR 1). The inhibition occurs through the connection of the CCA 1 and LHY proteins to the TOC 1 gene promoter, called evening element (EE) (Alabadi et al., 2001). The transcription factors CCA1 and LHY also act to repress other evening genes, such as the EFL3 and EFL4 (EARLY FLOWERING 3 and 4) genes. In addition to the repressing functions for the transcription of other genes, the transcription factors CCA1 and LHY also act as activators for the daytime activity genes PRR9 and PRR7 (Nagel \& Kay, 2012).

During the day, the PRR9 and PRR7 genes, together with other PRR genes (PRR1 and PRR5), act fundamentally to control the circadian clock. The expression of the PRR9 gene, induced by the CCA1 and LHY genes, begins right after dawn, followed by the other PRR genes, lasting for the entire luminous period, until the levels of transcripts / proteins of TOC 1 increase, during the night. Therefore, in addition to signalize the occurrence of daytime processes, the $P R R$ genes inhibit the expression of morning genes (CCA 1 and LHY) during the day, which allows a gradual increase of the TOC 1 gene expression, which indicates that the evening period is approaching (Nakamichi et al., 2010; Farre \& Liu, 2013). Recently, studies showed that the expression of the PRR7 gene, in addition to being regulated by light, also responds to the sugar levels originated from photosynthesis. Therefore, by dawn, with the beginning of the photosynthesis activity and the production of sugars, the expression of this transcription factor is induced (Haydon et al., 2013).

The components of the afternoon phase include the genes of the REVEILLE family (RVE8, RVE4 and RVE6). These genes act in an opposite manner than the morning genes CCA1 and LHY, that is, instead of repressing the induction of the evening action gene TOC1, the RVE transcription factors induce their expression (Harmer et al., 2000). Finally, the components of the evening phase are mainly represented by the transcription factors TOC 1 and PRR5 (Hsu \& Harmer, 2014). These genes are responsible for repressing the expression of the CCA1 and LHY genes, which, as shown, 
are genes whose activities begin by dawn (Pokhilko et al., 2012). Thus, the circadian clock is regulated by the action of transcription factors that act according to a feedback cycle, in which one inhibits or induces the action of the other.

\section{CIRCADIAN CLOCK AND THE EFFICIENCY OF HERBICIDES}

The high adoption of the use of herbicides to manage weeds in post-emergency situations, together with broader harvest areas, has demanded work-shifts that are more extensive than in the past. This causes herbicides to be applied over varied times and environmental conditions, which may lead to a higher or lower efficiency. This variation in control is attributed to the effect of the application time of the herbicide (time of day effect) (Stopps et al., 2013). Since these products affect several physiological processes in weeds, it is expected that the application time in relation to the circadian clock of plants is fundamental for its full effect (Martinson et al., 2002).

Several studies have evaluated the effect of the application time of herbicides on weeds. The efficiency of herbicides used in post-emergency situations in the soybean, such as chlorimuron-ethyl, glyphosate and imazethapyr, depends on the application time (Stopps et al. 2013). In another study, higher control levels for the Ambrosia artemisifolia, Amaranthus sp. and Abutilon theophrasti plants were obtained in herbicide applications between 9 a.m. and 6p.m. The same application interval (between 9 a.m. and 6 p.m.) offered higher control levels for weeds with glyphosate and glufosinate (Martinson et al., 2005). Considering the application time of atrazine and bromoxynil between 6 a.m. and 12 a.m., the best weed control in corn was obtained between 12 p.m. and 3 p.m. (Stewart et al., 2009). In the same study, when dicamba and glufosinate were sprayed on several weed species, the best control indices occurred between 9 a.m. and 6 p.m. Some factors may explain the variations in relation to the efficiency of post-emergent herbicides on weeds, in response to the circadian clock (application time). Among them are the morphological and physiological changes, such as leaf movements, thickness of the epicuticular wax, the metabolic rate, as well as variations in environmental factors, such as the wind speed, the presence of dew, temperature, and the relative air humidity (Stopps et al., 2013). These factors change the interception, absorption and translocation of herbicides (Stewart et al., 2009).

The variation in the leaf position (nyctinasty) considerably affects the efficiency of herbicides, since the interception area changes (Figure 3). Abutilon theophrasti plants with leaves on a $-80^{\circ}$ leaf angle when glyphosate was applied showed lower control than the ones with $\mathrm{a}-10^{\circ}$ angle. The variation on the leaf angle occurred in response to the application time of the herbicide. At 2 pm., a time in which high luminosity is available, the leaf angle was $-10^{\circ}$, while at 8 p.m. (low light availability), the angle was $-80^{\circ}$ (Mohr et al., 2007). In this study, grass plants showed no changes in relation to the leaf angle. This occurs because nyctinastic movements occur mainly in plants that belong to the Fabaceae and Oxalidaceae families. The change in the leaf angle occurs due to rhythmic changes in the turgidity on the pulvinus cells (ventral and dorsal motor cells regulated by $\mathrm{K}^{+}$and $\mathrm{Cl}^{-}$flows), a specialized structure that is located on the basis of the petiole.

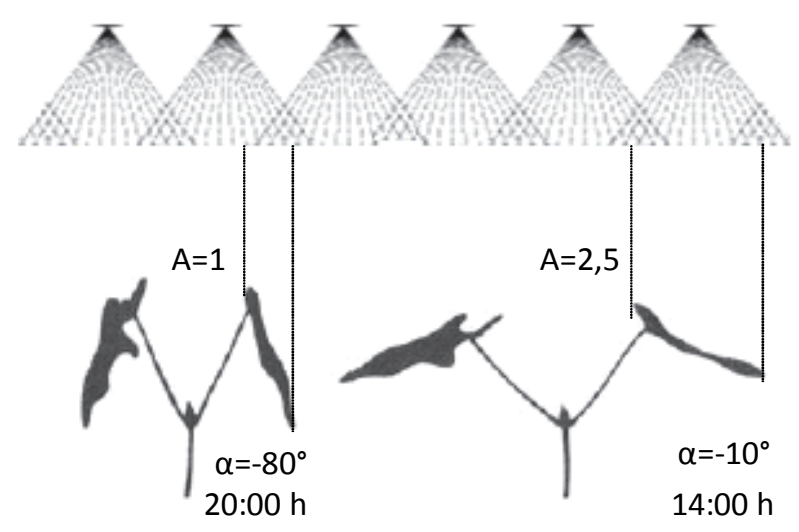

Adapted from McClung et al. (2006).

Figure 3 - In some weed species, the herbicide interception area (A) changes according to the application time and the leaf angle $(\alpha)$. 
The light directly affects the leaf movements through phytochromes, which, after realizing the luminous signs, synchronize the circadian clock in a way that leaf angles and leaflets change (Taiz \& Zeiger, 2006). Other examples of reduction of interception in the efficiency of herbicides due to leaf movements may be found in Sesbania exaltata (Norsworthy et al., 1999) and A. theophrasti (Sellers et al., 2003).

Variations in the photosynthesis rate are directly related to the efficiency of the glyphosate herbicide in A. theophrasti. Studies in the field and in greenhouses showed that glyphosate applications during a period with higher photosynthesis rate (between 10:30 a.m. and the sunset) offered better control levels. This effect is related to the fact that, because it is a herbicide with systemic action, high photosynthesis rates increase the transportation of metabolites in the plant, allowing the increment of the glyphosate translocation (Waltz et al., 2004). Some weed species are less sensitive to glyphosate since they show lower herbicide translocation (Shaner, 2009; Galon et al., 2013). Therefore, herbicide application at times of high photosynthesis activity favor a better action of the glyphosate herbicide to manage weeds, mainly in areas with the presence of species with reduced herbicide translocation. However, other factors must be taken into consideration, since the times of higher photosynthesis activity may coincide with lower relative humidity periods - another important factor for the efficiency of applications.

As described, several experiments showed that the efficiency of herbicides activated by light, such as glufosinate and glyphosate, is directly related to the circadian clock. The mode of action of glufosinate involves the inhibition of the glutamine synthetase (GS) enzyme, whose activity oscillates in relation to the circadian clock (Duke et al., 1978). The glyphosate herbicide, in turn, inhibits reactions from the shikimic acid pathway, which is important for the growth and development of plants. It is known that light affects some essential enzymes on this biochemical pathway (McCue \& Conn, 1990), and therefore is related with the herbicide efficiency.
The herbicides that inhibit photosystem I, such as paraquat and diquat, sequestrate electrons during the photochemical phase of photosynthesis. These herbicides create free radicals that, after self-oxidation, produce reactive oxygen species (ROSs) responsible for the peroxidation of lipids, cellular leakage and the death of the vegetal tissue. However, although the activity of the paraquat herbicide is related to the photosynthesis process (light dependent), the control of weeds is favored by applications made during the evening (Norsworthy et al., 2011). In a study with Arabidopsis thaliana, it was observed that both the production of ROSs $\left(\mathrm{H}_{2} \mathrm{O}_{2}\right.$-hydrogen hydroxide) and the activity of catalase enzymes $\left(\mathrm{H}_{2} \mathrm{O}_{2}\right.$ detoxifying enzymes) are regulated by the circadian clock, most precisely by the CCA1 gene (Lai et al., 2012). At 12 p.m., the amounts of $\mathrm{H}_{2} \mathrm{O}_{2}$ and catalases were higher in comparison to the evaluations conducted at 12 a.m. Since the transcription of the CCA1 gene reduces as the nighttime approaches (Lu et al., 2009), the activity of catalase enzymes also decreases, making plants more sensitive to the oxidative stress caused by the application of the paraquat herbicide during the evening.

Thus, it is observed that the efficiency of a certain herbicide varies throughout the cycle of the circadian clock. Some herbicides present better efficiency when applied early in the day, others, at noon, while others, during the evening. Therefore, understanding the bases of the circadian clock, as well as knowing the mechanism of action of herbicides, is fundamental to obtain better weed control.

\section{CIRCADIAN CLOCK AND RESISTANCE TO THE GLYPHOSATE HERBICIDE}

Recently, the resistance to glyphosate in A. thaliana plants was attributed to a dysfunction (mutation) of phytochrome $\mathrm{B}$ (phyB), which receives light on the red (650-680 nm) and far red (710-740 nm) ranges (Sharkhuu et al., 2014). Mutant plants are insensitive to the herbicide, also indicating that the circadian clock would be related to the differential tolerance to glyphosate. According to this study, a dysfunction on this 
photoreceptor would change the activity of the biochemical pathway of shikimate, consequently causing an increase on the amounts of gene transcripts that participate on this pathway, such as the deoxy-D-arabino heptulosonic synthase 1 (DAHPS1), shikimate kinase 1 (SK1), dehydroquinate synthase (DHQS) and 5-enolpyruvylshikimate-3phosphate-synthase (EPSPS) enzymes (Figure 4).

The DAHPS1 and SK1 genes have lightregulated transcription factor connection sites (TFSs), as well as the gene that regulates the circadian clock CCA1 (Figure 2). In turn, the DHQS and EPSPS genes show motifs on the promoting region that allow the association of phytochrome interacting factors (PIFs), which respond to the phyB activity. PIFs are transcription factors that accumulate under low luminosity conditions, in dense vegetation, where the R:FR relationship is low (Shen et al., 2007). The PIF proteins are involved in the response of the plant to the low light quality, known as "initialism" (Vidal et al., 2008). Therefore, the presence of TFSs related both to the phytochrome and the circadian clock may explain the reason why a light receptor may be the cause of the resistance of Arabidopsis to the glyphosate herbicide.

Under low R:FR relation conditions, the proportion of phyB in the active form (Pfr) tends to decrease, which leads to a higher activity of the PIF genes, which, in turn, inhibit the expression of genes that regulate the circadian clock and the shikimate lifecycle (Figure 4). However, when there was a phyB photoreceptor with a dysfunction (mutation), the reduced quality of the light (lower F:FR relation) did not change the amount of phyB on the Pfr (active) form. Therefore, since phyB in the Pfr form inhibits the expression of PIF genes, the activity of the shikimate pathway increases due to the higher expression of the genes that constitute it, among them, the EPSPS gene, which is the action site of the glyphosate herbicide. Therefore, the increase in the EPSPS gene expression contributes to increase the amount of the enzyme EPSPS, causing a higher tolerance of the plant to the herbicide. The highest activity of the shikimate pathway was also reported on a Convulvus arvensis population, explaining the greater tolerance

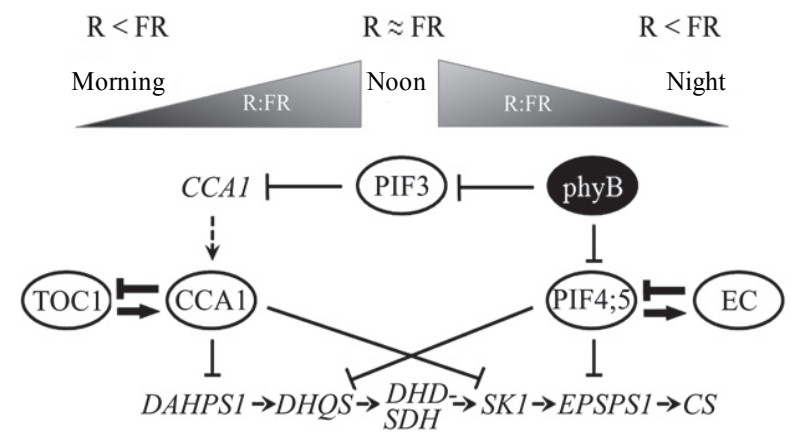

Suggested by Sharkhuu et al. (2014).

Figure 4 - Relationship between the light quality (R:FR), the phytochrome B (phyB) activity, the circadian clock and the shikimate metabolic pathway.

to the glyphosate herbicide (Westwood \& Weller, 1997). Similarly, the resistance to the glyphosate herbicide in some weeds is related to the greater expression of the EPSPS gene, as documented in populations resistant to Lolium rigidum (Baerson et al., 2002) and Conyza bonariensis (Dinelli et al., 2008). However, in both cases, the causes for greater activity of the shikimate pathway and greater expression of the EPSPS gene were not investigated.

\section{FINAL REMARKS}

The circadian clock has fundamental roles in the regulation of morphological and physiological processes in plants. It is a cyclic phenomenon, with endogenous regulations regulated by the activity of photoreceptors, which, after perceiving the luminous signals, begin the metabolic cascade on plants. Phytochrome B (phyB) is the most important photoreceptor, and its activity is directly related to the quality of the light (R:FR ratio). The circadian clock is closely related to the efficiency of several herbicides in many weeds. Characteristics such as leaf movements, photosynthesis rate, absorption and translocation of the herbicide and expression of genes of metabolic pathways in which the herbicides act are regulated by signals from phytochromes and/or by regulating the circadian clock. These processes explain the reasons why herbicides sprayed at certain times of the day may be 
more efficient. Therefore, from the perspective of the weed science, knowing the physiogenetic bases of the circadian clock in plants is fundamental, because it provide specific contributions, such as the best time for certain herbicide to be applied, as well as the reasons why differences in the efficiency of an herbicide occur, depending on the application time and weed specie.

\section{ACKNOWLEDGEMENTS}

To professor Ribas Antônio Vidal (UFRGS), for his contributions in the elaboration of this manuscript, and to CNPq, for scholarship and fellowship given to the first and second authors, respectively.

\section{LITERATURE CITED}

ALABADI, E. et al. Reciprocal regulation between TOC1 and LHY/CCA1 within the Arabidopsis circadian clock. Science, v. 293, n. 5531, p. 880-883, 2001.

BAE, G.; CHOI, G. Decoding of light signals by plant phytochromes and their interacting proteins. Ann. Rev. Plant Biol., v. 59, n. 1, p. 281-311, 2008.

BAERSON, S. R. et al. Investigating the mechanism of glyphosate resistance in rigid ryegrass (Lolium rigidum). Weed Sci., v. 50, n. 6, p. 721-730, 2002.

DINELLI, G. et al. Physiological and molecular bases of glyphosate resistance in Conyza bonariensis biotypes from Spain. Weed Res., v. 48, n. 3, p. 257-265, 2008.

DUKE, S. H. et al. Oscilations in the activities of enzymes od nitrato reduction and ammonia assimilation in Glycine max and Zea mays. Physiol. Plant., v. 42, n. 3, p. 269-276, 1978.

FARRE, E. M.; LIU, T. The PRR family of transcriptional regulators reflects the complexity and evolution of plant circadian clocks. Curr. Opin. Plant Biol., v. 16, n. 5 , p. 621-629, 2013.

GALON, L. et al. Glyphosate translocation in herbicide tolerant plants. Planta Daninha, v. 31, n. 1, p. 193-201, 2013.

FRANKLIN, K. A.; LARNER, V. S.; WHITELAM, G. C. The signal transducing photoreceptors of plants. Inter. J. Develop. Biol., v. 49, n. 5-6, p. 653-664, 2005.

HARMER, S. L. et al. Orchestrated transcription of key pathways in Arabidopsis by the circadian clock. Science, v. 290, n. 5499, p. 2210-2213, 2000.
HAYDON, M. J. et al. Photosyntetic entrainment of the Arabidopsis thaliana circadian clock. Nature, v. 502, n. 7473, p. 689-692, 2013.

HAZEN, S. P. et al. Exploring the tanscriptional landscape of plant circadian rhythms using genome tiling arrays. Genome Biol., v. 10, n. 2, p. 1-12, 2009.

HSU, P. Y; HARMER, S. L. Whells withim wheels: the plant circadian system. Trends Plant Sci., v. 19, n. 4, p. 240-249, 2014.

IMAIZUMI, T. Arabidopsis circadian clock and photoperiodism: time to think about location. Curr. Opin. Plant Biol., v. 13, n. 1, p. 83-89, 2010.

JIAO, Y. L. et al. Light-regulated transcriptional networks in higher plants. Nature Rev. Gen., v. 8, n. 3, p. 217-230, 2007.

LAI, A. G. et al. CIRCADIAN CLOCK-ASSOCIATED 1 regulates ROS homeostasis and oxidative stress responses. Proc. Nat. Acad. Sci. USA, v. 109, n. 42, p. 17129-17134, 2012.

LU, S. X. et al. CIRCADIAN CLOCK ASSOCIATED 1 and LATE ELONGATED HYPOCOTYL funtion synergistically in the circadian cloch of Arabidopsis. Plant Physiol., v. 150, n. 2, p. 834-843, 2009.

MARTINSON, K. B. et al. Circadian response of annual weeds to glyphosate and glufosinate. Chronobiol. Intern., v. 19, n. 2, p. 405-422, 2002.

MARTINSON, K. B. et al. Time of day application effect on glyphosate and glufosinate efficacy. Crop Management, v. 4, n. 1, p. 1-7, 2005.

MÁS, P.; YANOVSKY, M. J. Time for circadian rhythms: plants get synchronized. Curr. Opin. Plant Biol., v. 12, n. 5, p. $574-579,2010$.

McCLANG, C. R. et al. Plant circadian rhythms. Plant Cell, v. 18 , n. 4 , p. 792-803, 2006.ou McClung

McCUE, K. F.; CONN, E. E. Induction of shikimic acid pathway enzymes by light in suspension cultured cells of parsley (Petroselinum crispum). Plant Physiol., v. 94, n. 2, p. 507-510, 1990.

MOHR, K. et al. Application time of day influences glyphosate efficacy. Weed Technol., v. 21, n. 1, p. 7-13, 2007.

NAGEL, D. H.; KAY, S. A. Complexity in the wiring and regulation of plant circadian networks. Curr. Biol., v. 22, n. 16, p. 648-657, 2012. 
NAGY, F.; SCHÄFER, E. Phytochromes control photomorphogenesis by differentially regulated, interacting signaling pathways in higher plants. Ann. Rev. Plant Biol., v. 53, n. 1, p. $329-355,2002$.

NAKAMICHI, N. et al. PSEUDO-RESPONSE REGULATORS 9, 7, and 5 are transcriptional repressors in the Arabidopsis circadian clock. Plant Cell, v. 22, n. 3, p. 594-605, 2010.

NORSWORTHY, J. K. et al. Evaluation of combinations of paraquat plus photosystem II-inhibiting herbicides for controlling failed stands of maize (Zea mays). Crop Protec., v. 30, n. 3 , p. $307-310,2011$.

NORSWORTHY, J. K. et al. Diurnal leaf movement effects on spray interceptation and glyphosate efficacy.

Weed Technol., v. 13, n. 3, p. 466-470, 1999.

PFEIFFER, A. et al. Interaction with plant transcription factors can mediate nuclear import of phytochrome B. Proc. Nat. Acad. Sci., v. 109, n. 15, p. 5892-5897, 2012.

POKHILKO, A. et al. The clock gene circuit in Arabidopsis includes a repressilator with additional feedback loops. Mol. Syst. Biol., v. 8, 2012.

ROCKWELL, N. C. et al. Phytochrome structure and sinaling mechanisms. Ann. Rev. Plant Biol., v. 57, n. 1, p. 837-858, 2006.

SELLERS, B. A. et al. Diurnal fluctuations and leaf angle reduce glufosinate efficacy. Weed Technol., v. 17, n. 2, p. 302-306, 2003.

SHANER, D. L. Role of translocation as a mechanism of resistance to glyphosate. Weed Sci., v. 57, n. 1, p. 118-123, 2009.
SHARKHUU, A. et al. A red and a far-red ligth receptor mutation confers resistance to the herbicide glyphosate. Plant J., v. 78, n. 6, p. 912-926, 2014.

SHEN, Y. et al. Phytochrome induces rapid PIF5 phosphorylation and degradation in response to red-light activation. Plant Physiol., v. 145, n. 3, p. 1043-1051, 2007.

SONG, Y. H. et al. Similarities in the circadian clock and photoperiodism in plants. Curr. Opin. Plant Biol., v. 13, n. 5, p. 594-603, 2010.

STEWART, C. L. et al. Time of day impacts postemergence weed control in corn. Weed Technol., v. 23, n. 3, p. 346-355, 2009.

STOPPS, G. J. et al. The effect of time of Day on the activity of postemergence soybean herbicides. Weed Technology, v. 27, n. 4, p. 690-695, 2013.

TAIZ, L.; ZEIGER, E. Plant physiology. 4.ed. Sunderland: Sinauer Associates, 2006.

VIDAL, R. A. et al. Initialism: a new term to describe the first mechanism of negative interaction between weeds and crops. J. Plant Dis. Protec., v. 21, n. 1, p. 95-98, 2008.

WALTZ, A. L. et al. Glyphosate efficace on velvetleaf varies with application time of day. Weed Technol., v. 18, n. 4, p. 931-939, 2004.

WESTWOOD, J. H.; WELLER, S. C. Cellular mechanisms influence differential glyphosate sensitivity in field bindweed (Convolvulus arvensis) biotypes. Weed Sci., v. 45, n. 1, p. 2-11, 1997.

WIJNEN, H.; YOUNG, M. W. Interplay of circadian clocks and metabolic rhythms. Ann. Rev. Genet., v. 40, n. 1, p. 409-448, 2006. 